\title{
Historical Lesson Plan with Project Based Learning in Senior High School during Pandemic
}

\author{
Valentinus Vembriyanto, and Erni Murniarti
}

\section{ABSTRACT}

\begin{abstract}
The pandemic event that occurred in Indonesia affected all lines of community life, one of which was in the field of education. During the pandemic, learning in schools was carried out with distance learning with an online model (in the network). The Minister of Education and Culture has planned a policy, namely "Free Learning" with the aim of creating enjoyable learning. Freedom of learning which is meant is freedom in thinking, opening up broad opportunities for educators and students to innovate and improve the quality of learning independently. A new challenge for educators, especially for history teachers, is to create innovative and learner-focused learning designs. Designing an innovative and simple lesson plan must still give place to the character education process. This is answered by using a project-based learning model, in which this learning model provides broad opportunities for students to explore and innovate in the knowledge being learned. With this the goal of independent learning will be achieved for teachers and students, so that education in Indonesia will produce quality education.
\end{abstract}

Keywords: independent learning, innovation, character
Published Online: March 29, 2021

ISSN: $2736-4534$

DOI $: 10.24018 /$ ejedu.2021.2.2.68

Valentinus Vembriyanto

Universitas Kristen, Indonesia

(e-mail: vembrific@gmail.com)

Erni Murniarti

Universitas Kristen, Indonesia

(e-mail: erni.murniarti@ uki.ac.id)

\section{INTRODUCTION}

The Covid-19 pandemic has an impact on all lines of life of Indonesian people. One of the impacts experienced is that learning activities are carried out remotely, where all students learn at their respective homes. Distance learning is a solution to overcome difficulties in implementing face-to-face learning. This presents a challenge to all elements and levels of education to keep the class active even though studying at home. (Herliandry, L. D., Nurhasanah, N., Suban, M. E., \& Kuswanto, H., 2020). In distance learning, until now there has been no policy that clearly regulates the learning design format. In this case all subject teachers are expected to be able to create learning scenarios and design distance learning methods and models.

Learning that is currently carried out using network technology or often called learning in networks (online). In distance learning, there are 4 things as keys in online learning, namely the ability of teachers to use technology, planned and effective learning, unifying students' perceptions and concentrations, and strengthening character education. (Mustusilo, Kompas.com) The four things above are a new challenge for every teacher to create learning designs that answer current needs. There are more demands for education in SMA by looking at students who are considered more capable in utilizing technology. One of the lectures was that the teacher was able to design learning that empowered students to learn actively and proactively.

Starting from the problem of distance learning or online, it becomes interesting when educators share their views on effective learning designs. The design that will be discussed is online learning in history subjects at Pangudi Luhur Jakarta High School. Hopefully this article can provide inspiration or ideas for educators to make it a reference in preparing effective learning for independent learning education.

\section{THEORITICAL REVIEW}

\section{A. Freedom of Learning}

Before this pandemic occurred in Indonesia, the Minister of Education and Culture had issued an educational program called "Free Learning". The concept of "Free Learning" was issued by the Minister of Education and Culture (Mendikbud) of the Republic of Indonesia as an answer to conventional education problems, namely education that measures learning success only from the results of the assessment. According to Mendikbud, independent learning is a fun curriculum application, coupled with the development of innovative thinking. (Fathan, 2020) The teacher implements an innovative and proactive learning design that will foster a positive attitude for students in following the learning process. The purpose of independent learning is so that teachers, students, and parents have a happy atmosphere. (Thank God, 2020)

According to the minister of education and culture, the Merdeka Learning policy will give every educational institution independence to make changes in innovation. The concept created by each educational institution must adapt to 
the conditions of society and the environment. The strategy prepared by the Minister of Education and Culture is teacher quality. The reason is that teachers cannot be replaced by technology, because technology is a tool in improving the quality of learning. (Prayoga, 2020).

\section{B. Online Learning Concept}

Online learning is very well known among the public and academics with the term online learning (online learning). Another term that is very commonly known is distance learning. Online learning is learning that takes place in a network where the teacher and the one being taught do not meet face to face directly. (Pohan, 2020) Online learning is basically learning that is done virtually through available virtual applications. However, online learning must pay attention to the competencies to be taught. (Syarifudin, 2020) Learning online, or online, is a translation of the term online which means connected to a computer network. In other words, it is learning without face to face directly between teachers and students, but carried out via the internet (online) from different places. (Santika, 2020) Thus the concept of online learning is a learning interaction that has been designed according to the school curriculum remotely between educators and students mediated by internet devices and networks. Online class learning has been a choice of study mode for those who do not intend to attend the classroom, mostly the millennials. It suits those engaged with their work, live with low economic level, or live in an area far away from the university due to its flexible time, tuition, and place. What they need is just an internet connection (Murniarti, 2020)

Online learning is implemented by educators as learning that utilizes online media. The concept of teacher learning patterns and media can be described as follows:

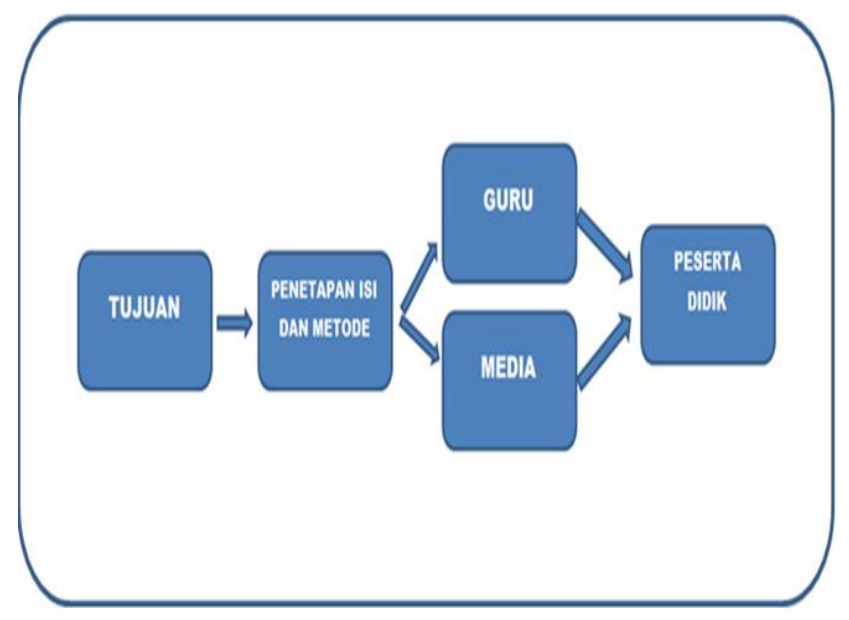

The learning pattern of this media teacher is a change in learning patterns that occurs due to a change in the role of the teacher in learning activities, where the teacher and the media have an equal role in carrying out their function to convey the content or learning material. (Riyana, 2020). Media is a tool in explaining learning material, the role of the teacher is getting smaller and students have more time to explore learning. This concept really answers the needs of distance learning via network. The advantages of online learning include learning that does not require classrooms, teachers do not need to face face to face with students, it is not limited by time and space. (Santika, 2020)

\section{DISCUSSION}

\section{A. Plan for implementing independent learning $(R P P)$ in history subjects}

Today, History Lessons are a challenge for educators, especially in this online learning. Experience that occurs faceto-face in the class of students who are not interested in learning history. The question is whether it would be more interesting if it was carried out online? The answer is there is no certainty that the lessons are not that much more interesting than before. The ideal phenomenon is that the history learning curriculum is designed not only to answer the problem of when, where and why historical events occur. But looking for an answer to 'How did you know this incident?'. So that learning history functions more as a social reconstruction. Reconstruction of past events, to solve problems in the present, in order to plan for a better future. (Umamah, 2017) Historical learning needs to be emphasized in the search for the meaning of a historical event that is associated with the values of life. History has a reflective function in anti-inspiration, learning history can build wisdom in the life of society and nation, history make man wise. (Sardiman, 2017)

In history learning, a teacher needs to apply learning innovations designed to help students easily understand facts, events, concepts, and generalizations through empirical learning experiences. History learning needs to use a variety of media that have the potential to add insight and context to learning and improve historical learning outcomes. (Susilo and Sarkowi, 2018) Opportunities in carrying out history learning online, namely teachers / lecturers can use Whatsapp, Facebook, Instagram, Google Classroom, Zoom, Google Meet, Youtube, Discord, and virtual cultural heritage tours to support online learning. In addition, teachers / lecturers must include history learning which also focuses on the affective domain, so that character values are embedded that can be internalized into the daily lives of students / students. (Absor, 2020)

Opportunities to increase effective and fun learning according to the concept of independent learning need to be prepared with innovative learning designs. The historical RPP (Learning Implementation Plan) in the concept of Merdeka Belajar is a new concept regarding lesson planning that is adapted to the learning period during the pandemic which is carried out online. The lesson plans that are applied no longer follow a rigid lesson plan format, but teachers are free to choose, make, use and develop the format. The format prepared in the RPP Merdeka Belajar contains learning objectives, learning activities and assessments. (Kompasiana.com) With this simple thing, it requires teachers to be more innovative in preparing for learning, especially during this pandemic, teachers must be able to prepare lessons that are closely related to media and technology.

Free lesson plans for learning in History subjects essentially pay attention to the character of the learning, namely prioritizing character learning. Building national character can be started from anywhere, from literature to technology. However, what is needed from the start in this role is a "policy" to build the character of the nation itself ". (Nugroho, 2018) This emphasizes that in implementing these characters, it must be clear and contained in the things we have prepared. In preparing historical lesson plans that are in line with independent learning, it will be very beneficial for 
the success of learning if the learning model used is also very supportive of the process. The learning model used is "Project Based Learning". Project-based learning is a form of situated learning (Greeno, this volume) and it is based on the constructivist finding that students gain a deeper understanding of material when they actively construct their understanding by working with and using ideas. In projectbased learning, students engage in real, meaningful problems that are important to them and that are similar to what scientists, mathematicians, writers, and historians do. (Krajcik, Blumenfeld, 2006)

The project-based learning model puts forward the learning center for students (student center), where the teacher acts as a facilitator in learning. For learning history, this model is very contextual, where students will get to know history learning more closely even though what is being learned is a past event. In addition to contextual, students will find it very easy to explore the character values contained in an event they are learning. So that the meaning of the learning process is not just knowledge but there are values of life, namely character. The RPP framework for History subjects at Pangudi Luhur High School, Jakarta Indonesia is prepared by adjusting online learning.

Example of RPP Independent Learning Indonesian History Subjects:

LESSON PLAN FOR INDEPENDENT LEARNING

HISTORY SUBJECTS

Senior High School.

\begin{tabular}{|c|c|c|c|}
\hline BASIC COMPETENCIES & 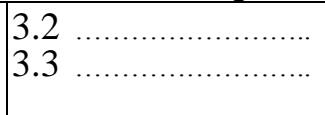 & $\begin{array}{l}\text { CLASS } \\
\text { SEMESTER } \\
\text { TIME }\end{array}$ & $\begin{array}{l}\cdots \ldots+\cdots \\
\cdots \cdots \\
\cdots \cdots \cdots\end{array}$ \\
\hline \multicolumn{4}{|l|}{ LEARNING OBJECTIVES. } \\
\hline \multicolumn{4}{|l|}{$\begin{array}{l}\text { ASSESSMENT } \\
\text { 3.2 Students are required to: } \\
\bullet \quad \ldots \ldots \ldots \ldots \ldots \ldots \ldots \ldots \\
\bullet \quad \ldots \ldots \ldots \ldots \ldots \ldots \ldots \ldots \\
4.2 \text { Students are required to: } \\
\bullet \quad \ldots \ldots \ldots \ldots \ldots \ldots \ldots\end{array}$} \\
\hline \multicolumn{4}{|c|}{$\begin{array}{l}\text { VALUE } \\
\ldots \ldots \ldots \ldots \ldots \ldots \ldots \ldots \ldots \ldots \ldots \ldots \ldots \ldots \ldots \ldots \ldots \ldots \ldots\end{array}$} \\
\hline \multicolumn{4}{|c|}{$\begin{array}{l}\text { LEARNING FOCUS / MATERIALS } \\
\ldots \ldots \ldots \ldots \ldots \ldots \ldots \ldots \ldots \ldots \ldots\end{array}$} \\
\hline \multicolumn{4}{|c|}{ LEARNING SCENARIO ( 8 x 70 minutes) } \\
\hline \multicolumn{4}{|l|}{ The first meeting } \\
\hline \multicolumn{4}{|l|}{ Second meeting } \\
\hline \multicolumn{4}{|l|}{ Third Meeting } \\
\hline \multicolumn{4}{|c|}{ LEARNING MODELS / APPROACHES } \\
\hline \multicolumn{4}{|c|}{ 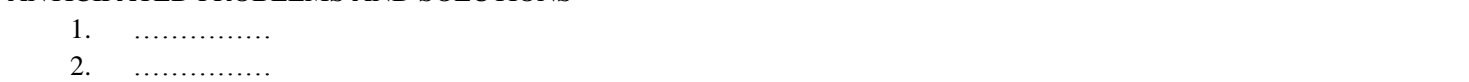 } \\
\hline $\begin{array}{l}\text { ASSESSMENT } \\
\text { Assessment Techniques } \\
\begin{array}{cr}1 . & \ldots \ldots \ldots \ldots \ldots \\
2 . & \ldots \ldots \ldots \ldots \ldots\end{array}\end{array}$ & & & \\
\hline 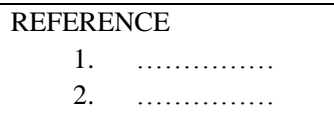 & & & \\
\hline
\end{tabular}

Knowing

Jakarta, 13 July 2020

Headmaster of SMA Pangudi Luhur Jakarta

Classroom Teacher 


\section{Sample of Lesson Plan for History Subject:s \\ LESSON PLAN FOR INDEPENDENT LEARNING HISTORY SUBJECTS SMA PANGUDI LUHUR JAKARTA}

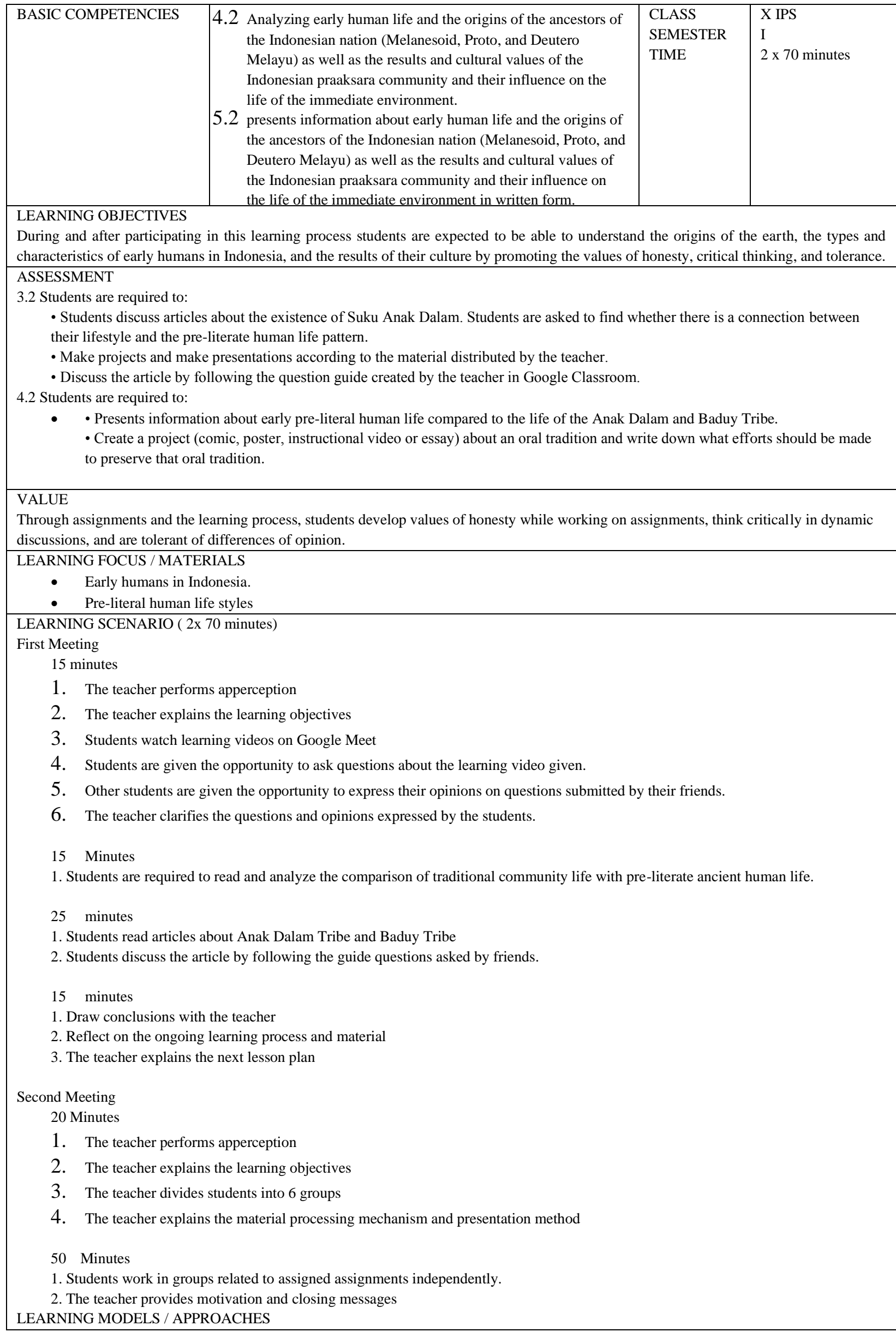




\begin{tabular}{|c|c|}
\hline $\begin{array}{l}\text { Problen } \\
\text { Comm }\end{array}$ & $\begin{array}{l}\text { ased Learning } \\
\text { ative learning }\end{array}$ \\
\hline ANTIC & ITED PROBLEMS AND SOLUTIONS \\
\hline 1 . & Students do not pay attention to the material in Google Meet. Students are asked to turn on the camera during learning. \\
\hline 2. & $\begin{array}{l}\text { The possibility of students not doing assignments uploaded on Google Classroom - students are reminded that each assignment } \\
\text { given by the teacher is mandatory and if they do not do it, it will greatly affect the value of history subjects on the report card. }\end{array}$ \\
\hline 3. & $\begin{array}{l}\text { The possibility of students being not active in discussions - students are reminded that activity in the classroom is one of the } \\
\text { important assessments that must be fulfilled }\end{array}$ \\
\hline 4. & The student may not pay attention to the power point broadcast - The teacher will broadcast it on Google Meet. \\
\hline ASSES & ENT \\
\hline Assessr & t Techniques \\
\hline 1. Attit & : Observations and journals \\
\hline 2. Knov & dge: Written test \\
\hline & ills: Performance \\
\hline REFER & $\mathrm{CE}$ \\
\hline 1 . & Ratna Hapsari dan M.Adil. 2017. Sejarah untuk SMA/MA Kelas X (Wajib): Jakarta : Penerbit Erlangga. \\
\hline 2. & Sumber internet relevan seperti historia.id \\
\hline
\end{tabular}

\section{Knowing}

Headmaster of SMA Pangudi Luhur Jakarta

Drs. Agustinus Mulyono
Jakarta, 13 July 2020

Classroom Teacher

Br. Valentinus Vembriyanto FIC

\section{CONCLUSION}

Freedom to learn is the right program to respond to the situation and condition of the Indonesian nation which is improving the quality of learning. In line with the government's program in overcoming the spread of Covid 19, this is the perfect time to realize the program planned by the Minister of Education and Culture. One of the programs that touches directly is the simplification or streamlining of lesson plans as a reference for educators in carrying out the learning process. Teachers are free to choose, make, use and develop the lesson plan format which is only 1 page. The essence of free learning is freedom in thinking, this leads to independence and flexibility in learning. It is very appropriate that change starts from educators, because educators are leaders in learning. Thus educators get the absolute opportunity to design an effective and characterful learning plan.

One of the effective models to answer the challenges in learning history is learning with a project based learning model, where this model emphasizes the activeness of students. This model provides a very broad space for students to explore and innovate in understanding the science that is being studied. In the lesson plan designed by the teacher, in addition to being very simple or lean, it still contains the concept of character learning. Not only is it a discourse in learning but also appears in the learning process. Thus the lesson plans which are required with this innovation are very effective for teachers and students in responding to the needs of today's education era.

\section{SUGGESTION}

In this regard, it is suggested that several things be considered as follows:

1) Creating a simple learning independent lesson plan must also pay attention to the conditions and situations of the school and students.

2) To develop an effective learning model, an approach and socialization is needed so that the model which is implemented is easy to understand and can be implemented according to the learning scenario;

3) The RPP provided above is an example of the implementation of learning at Pangudi Luhur Jakarta
High School, it is very open to criticism and suggestions for the development of the writing of the next work.

\section{REFERENCE}

Abidah, A., Hidaayatullaah, H. N., Simamora, R. M., Fehabutar, D., \& Mutakinati, L. (2020). The Impact of Covid-19 to Indonesian Education and Its Relation to the Philosophy of "Merdeka Belajar". Studies in Philosophy of Science and Education, 1(1), 38-49.

Absor, N. F. (2020). Pembelajaran Sejarah Abad 21: Tantangan dan Peluang dalam Menghadapi Pandemi Covid-19. CHRONOLOGIA, 2(1), 30-35.

Asfiati, A., \& Mahdi, N. I. (2020). Merdeka Belajar bagi Anak Kebutuhan Khusus di SLB Kumala Indah Padangsidimpuan. KINDERGARTEN: Journal of Islamic Early Childhood Education, 3(1), 59-69.

Dinda Agelia. 2020. Kebijakan-kebijakan Merdeka Belajar. https://www.kompasiana.com/dindaagelia2445.

Fathan Robby. 2020. Hardiknas 2020 Merdeka Belajar Di Tengah Covid-19. (http://jurnalposmedia.com/hardiknas-2020-merdeka-belajar-ditengahcovid-19).

Herliandry, L. D., Nurhasanah, N., Suban, M. E., \& Kuswanto, H. (2020). Pembelajaran pada masa pandemi covid-19. JTP-Jurnal Teknologi Pendidikan, 22(1), 65-70.

Krajcik, J. S., \& Blumenfeld, P. C. (2006). Project-based learning (pp. $317-$ 34). na.

Murniarti, E., \& Peter, R. (2020). STUDENTS'LEARNING ATTITUDES AS IMPACT OF ONLINE LEARNING MATERIALS. PalArch's Journal of Archaeology of Egypt/Egyptology, 17(4), 1744-1757.

Mustaghfiroh, S. (2020). Konsep "Merdeka Belajar" Perspektif Aliran Progresivisme John Dewey. Jurnal Studi Guru Dan Pembelajaran, 3(1), 141-147.

Nugroho, Riant. 2018. Kebijakan Membangun Karakter Bangsa. Jakarta:PT Elex Media Komputindo.

Pohan, A. E. (2020). Konsep pembelajaran daring berbasis pendekatan ilmiah. Penerbit CV. SARNU UNTUNG.

Prayogo. 2020. Peluang Reformasi Pendidikan Di Tengah Pandemi Covid19. (https://www.y.prayogo.kalderanews.com/2020/05/.)

Saleh, M. (2020, May). Merdeka Belajar di Tengah Pandemi Covid-19. In Prosiding Seminar Nasional Hardiknas (Vol. 1, pp. 51-56)

Santika, I. W. E. (2020). Pendidikan karakter pada pembelajaran daring. Indonesian Values and Character Education Journal, 3(1), 8-19.

Sardiman, S. (2017). Reformulasi Pembelajaran Sejarah: Sebuah Tantangan. ISTORIA: Jurnal Pendidikan dan Sejarah, 13(1).

Susilo, A., \& Sarkowi, S. (2018). Peran Guru Sejarah Abad 21 dalam Menghadapi Tantangan Arus Globalisasi. Historia: Jurnal Pendidik dan Peneliti Sejarah, 2(1), 43-50.

Syarifudin, A. S. (2020). Impelementasi pembelajaran daring untuk meningkatkan mutu pendidikan sebagai dampak diterapkannya social distancing. Jurnal Pendidikan Bahasa dan Sastra Indonesia Metalingua, 5(1), 31-34.

Syukri Bayumie, AP.,SE.,M.Si. 2020. Menakar Konsep Merdeka Belajar (https://intens.news/menakar-konsep-merdeka-belajar/).

Riyana, C. (2020). Konsep pembelajaran online. Modul Pembelajaran OnLine, 1. 
European Journal of Education and Pedagogy www.ej-edu.org

Umamah, N. (2017). Pembelajaran Sejarah Kesiapannya Menghadapi Tantangan Zaman.

Yamin, M., \& Syahrir, S. (2020). Pembangunan Pendidikan Merdeka Belajar

(Telaah Metode Pembelajaran). Jurnal Ilmiah Mandala Education, 6(1). 